\title{
Asymmetric Effects of Exchange Rate on Monetary Policy in Emerging Countries: A Non-Linear ARDL Approach in Uganda
}

\author{
Allan Kayongo ${ }^{1}$, Asumani Guloba ${ }^{2} \&$ Joseph Muvawala ${ }^{3}$ \\ ${ }^{1}$ Policy Research Planner, Policy Research and Innovation Department, National Planning Authority (NPA), Kampala, \\ Uganda \\ ${ }^{2}$ Director of Development Planning, National Planning Authority (NPA), Kampala, Uganda \\ ${ }^{3}$ Executive Director, National Planning Authority (NPA), Kampala, Uganda \\ Correspondence: Allan Kayongo, Policy Research and Innovation - National Planning Authority (NPA), Kampala, \\ Uganda.
}

Received: July 13, 2020

Accepted: August 7, 2020

Available online: August 27, 2020

doi:10.11114/aef.v7i5.4928

URL: https://doi.org/10.11114/aef.v7i5.4928

\begin{abstract}
Many money demand studies have been carried out on Uganda, however, these studies perceive and incorporate exchange rate as a linear determinant of real money demand. Indeed, exchange rate may have asymmetric effects on real money demand; with exchange rate appreciation having different effects from exchange rate depreciation. Therefore, this is the first study to estimate exchange rate asymmetries in Uganda, for the period 2008Q3 and 2018Q4. The study uses both the linear ARDL and non-linear ARDL methodologies to accomplish its goal. This is also done by incorporating an economic uncertainty index, which is critical, especially in light of the novel global coronavirus pandemic, that has disrupted trade, movement and supply chains. The error correction terms of both models are negative and significant, with the one of the non-linear ARDL twice as much as that of the linear ARDL. Indeed, the study confirms the existence of exchange rate asymmetries on Uganda's real money demand. In the linear ARDL model, exchange rate has a positive effect in the long run but a negative result in the short run. On one hand, the non-linear ARDL model reveals that an exchange rate depreciation of the Uganda Shillings negatively affects real money demand in the short run. On the other hand, an exchange rate appreciation positively effects real money demand. Notably, economic uncertainty has insignificant effects in both models, except for its lags in the non-linear model. The implication of these findings is that macro-economic policy management in Uganda should be cognizant of these asymmetric effects of exchange rate, for effective planning, policy and implementation.
\end{abstract}

Keywords: asymmetric, exchange rate, economic uncertainty, money demand stability, non-linear ARDL

JEL Classification: E41; E52; E6

\section{Introduction}

Money demand stability is critical for the design and implementation of monetary policy, especially because it makes it possible to predict the effect of a given amount of money supply on the aggregate economy (Friedman \& Schwartz, 1982; El-Rasheed, Abdullah \& Dahalan, 2017; Kayongo \& Guloba, 2018). The debate on money demand has largely been re-visited after the occurrence of the financial crisis (Bossone, 2014; Eggertsson \& Mehrotra, 2014). This debate is even more critical in the presence of global pandemics like the current novel global coronavirus pandemic. This is because disruptions in trade, movements and global supply chains, and the associated mitigative and lockdown policies affect money demand, money supply, economic activity and development.

Money demand is usually estimated as a function of a scale variable and opportunity cost variables; with national income specified as the scale variable and interest rates as the opportunity cost variables (Sriram, 2001). Mundell (1963) also postulated that in addition to income and interest rate, exchange rate is another determinant of money demand.

Most studies presume exchange rate to have symmetric effects on money demand (Kayongo \& Guloba 2018; Guloba \& Osoro, 2009). Exchange rate asymmetry in this case is defined as a phenomenon where exchange rate depreciations have different effects on money demand from exchange rate appreciations. For example, an exchange rate depreciation may have either wealth or expectation effects on money demand. Wealth effects of an exchange rate depreciation occur 
when an exchange rate depreciation increases money demand while expectation effects of an exchange rate depreciation occur when this depreciation reduces money demand (El-Rasheed et al., 2017; Arango \& Nadiri, 1981; Kayongo \& Guloba, 2018). Indeed, some studies have analysed this hypothesis that exchange rate may have asymmetric effects on money demand (Bahmani-Oskooee, Miteza \& Tanku, 2020; Bahmani-Oskooee \& Gelan, 2019; Bahmani-Oskooee, Kutan and Xi, 2013; Mahmood \& Alkhateeb, 2018). These exchange rate asymmetric effects can only be analysed by introducing non-linear adjustment processes; otherwise, currency depreciation may not have significant effects on money demand (Bahami-Oskooee et al., 2020; Bahmani-Oskooee \& Gelan, 2019).

Additionally, only a few money demand studies have included economic uncertainty factors in their estimation, yet it significantly impacts money demand (Greiber \& Lemke, 2005; Choi \& Oh, 2003; Atta-Mensah, 2004; Bahmani-Oskooee et al., 2013; Kayongo \& Guloba, 2018). Economic uncertainty effects on money demand stability are fourfold: positive; negative; concurrent positive and negative effect; and no effect at all. However, the effects of uncertainty on Uganda's money demand are not known with clarity, save for Kayongo and Guloba (2018) who find out that economic uncertainty doesn't have any effect for small money balances except for broader money balances.

Uganda's monetary policy is a compelling case to study. Commercial Bank interest rates are sticky downwards to changes in the Central Bank Policy Rate (CBR). For instance, Uganda has adopted an expansionary monetary policy stance with the Central Bank Rate (CBR) being maintained at 9 percent between October 2019 and February 2020. In fact, the CBR policy rate was further reduced by two percent, from 9 percent in February, 2020 to 7 percent in June, 2020. It was majorly to cushion the country from the effects of the novel coronavirus global pandemic. Notwithstanding, the effects of the pandemic, the commercial lending interest rates have not followed the CBR movements; remaining high, at rates averaging 24 percent. This shows that there might be some factors beyond the traditional money demand determinants that affect money demand. Such factors may include the asymmetric exchange rate effects and economic uncertainty effects.

Exchange rate stability is critical for proper planning by various economic actors. Uganda pursues a flexible exchange rate regime. In this regime, the price of the Uganda Shilling against the US Dollar is determined by the market forces of demand and supply. Notably, during the advent of the coronavirus pandemic, the Uganda Shilling depreciated by 4 percent against the US Dollar, from Ushs. 3,676.9 in February to Ushs. 3,844 by $23^{\text {rd }}$ March, 2020. Bank of Uganda explained this by the exit of offshore investors of Government securities, in search of safe-havens. For example, between $21^{\text {st }}$ February, 2020 and $13^{\text {th }}$ March, 2020, offshore holding of government securities declined by UShs. 130 billion. This was augmented by negative sentiments of various economic actors due to the pandemic effects. However, it isn't known with certainty a priori whether such depreciation tendencies are symmetric or asymmetric. This makes the current study timely so as to untangle these different monetary policy intricacies and better inform the economic management of the country.

The overall objective of the study, is to assess the symmetric and asymmetric effects of exchange rate on money demand and its stability; while incorporating an economic uncertainty index in Uganda, during 2008Q3 and 2018Q4. The contribution of this study is that it helps to fill the dearth in economic literature and macro-policy management regarding the asymmetric effects of exchange rate on money demand in Uganda and East Africa. The study will also help in better policy formulation, for example; getting information regarding the asymmetric exchange rate effects of money demand will show how to precisely respond to either exchange rate appreciation or exchange rate depreciation.

The inclusion of an economic uncertainty index is a major value addition in this regard, especially in light of the effects of the global coronavirus pandemic that have made many economic actors uncertain of the future. Additionally, if risk factors are not well articulated in monetary policy, resources will be channeled to unproductive sectors which do not impact highly on economic growth at the cost of the productive sectors. This ultimately has a negative impact on economic growth, production, employment and overall economic development (Kayongo \& Guloba, 2018).

The variables included in the estimation model include; real national income, interest rate spread, real exchange rate, inflation and an economic uncertainty index. The study is majorly based on Kayongo and Guloba (2018), but with an extension of estimating exchange rate asymmetries using the non-linear ARDL methodology. Consequently, stability tests are carried out to verify if Uganda's money demand is still stable amidst all these factors.

The rest of paper is structured as follows: Section Two analyses both the related theoretical and empirical literature. Section Three describes the methodology adopted by the study. Section Four presents and discusses the results while Section Five concludes and provides policy recommendations.

\section{Literature Review}

Theoretically, money demand studies have foundations in Fischer (1911) who determined that real money demand is a function of the level of transactions. The study argued that households and businesses demand money only for transaction purposes. However, Pigou (1917) argued that money is held for convenience purposes, especially because it 
has immediate purchasing power; acts as a store of value; and enables people to buy on favourable terms. Notwithstanding, Keynes (1935) criticized the previous theoretical stipulations because they didn't include interest rates as critical determinants of money demand. He therefore postulated the liquidity preference of money demand which contends that money is held for transaction, precautionary and speculative purposes.

On the other hand, Baumol (1952) and Tobin (1956) contended that money held for transaction purposes is also affected by interest rates. They presented a model in which the costs (interest foregone) and benefits (convenience) of holding money were analysed. An individual therefore decides to build a wealth portfolio including both money and non-monetary assets. Friedman (1956) concluded that economic agents hold a certain quantity of real money as opposed to nominal money balances. This is especially because inflation erodes the purchasing power of money.

In summary, Sriram (2000) postulates that all theoretical specifications of money demand point to the general specification that money demand is a function of both a scale variable and opportunity cost variables. In many cases, national income is specified as the scale variable while the opportunity cost variables include inflation, interest rates and foreign interest rates among others.

Most money demand studies in Uganda include exchange rate as a major determinant of money demand (Kayongo \& Guloba, 2018; Guloba \& Osoro, 2009; Nyorekwa, 2007; Kararach, 2002; Katarikawe \& Sebudde, 1999; Atingi-Ego \& Matthews, 1996; Kateregga, 1993) among others, while others don't (Nachega, 2001). The studies that include exchange rate as a money determinant either confirm wealth effects or expectation effects of exchange rate effects on money demand. For example, (Opolot, 2007; Nabiddo, 2007) found out that economic agents reduce their demand for Uganda Shillings whenever there is an exchange rate depreciation while Kararach (2002) found out that economic agents increase their demand for Uganda Shillings in the presence of an exchange rate depreciation. Other studies show that exchange rate can either have wealth effects or speculation effects on money demand, depending on the monetary aggregate analysed. For example, Kayongo (2017) finds out that exchange rate has speculation effects on real broad money (M2) in the short run but instead has wealth effects on real broad money M3 in the long run. Additionally, exchange rate effects on money demand also depend on the time span of analysis because short run actions of economic actors may be different from those in the long run.

However, all the Ugandan money demand studies assume exchange rate to have symmetric effects on money demand (Kayongo, 2017; Guloba \& Osoro, 2009; Nabiddo, 2007; Opolot, 2007; Kararach, 2002; Kayongo \& Guloba, 2018 among others). This is a simplistic assumption that has effects on the final effects of exchange rate on money demand and its stability. It is important to note that in practice, exchange rate may have asymmetric effects on money demand with exchange rate appreciation having a different effect from exchange rate depreciations (Bahami-Oskooee et al., 2020; Bahmani-Oskooee \& Gelan, 2019).

Literature regarding both asymmetric effects of exchange rate on money demand has been mainly done on developed and industrialized countries than on developing and African countries (Bahmani-Oskooee et al., 2020; Bahmani-Oskooee \& Gelan, 2019; Bahmani-Oskooee \& Bahmani, 2015; Kones, 2014). For example (Bahmani-Oskoee et al., 2019) found out that there exist asymmetric exchange rate tendencies in Asia, specifically for India, Indonesia, Korea and Philippines. Bahmani-Oskooee and Gelan (2019) revealed that exchange rate changes had short-run effects in 16 African countries of the 18 countries that were studied. These exchange rate effects were asymmetric in 11 countries of the 16 analysed. Bahmani-Oskooee and Bahmani (2015) also found out that an exchange rate appreciation or depreciation could affect the demand for money in an asymmetric manner.

Similarly, literature on economic uncertainty effects on money demand is also scanty for Uganda and the East Africa region (Kiptui, 2014; Kayongo \& Guloba, 2018). Risk averse households or consumers facing a stochastic income stream increase precautionary saving. Increase in uncertainty also depresses output, consumption, investment and hours worked, especially when there exist non-convex costs of adjustment (Bloom, 2009; Basu \& Bundick, 2015). However, this doesn't hold in a general-equilibrium neoclassical model with a representative firm and a consumer with additively time-separable preferences (Kayongo \& Guloba, 2018). Most importantly, it is argued that negative uncertainty shock impacts are offset by monetary policy during normal times.

Economic uncertainty affects the economy's demand side through its impact on household consumption and firm investment, but also, supply side effects on the economy exist (Bloom, 2009; Bloom, Kose \& Terrone, 2013). A keen literature survey shows that economic uncertainty effects on monetary policy are four-fold, that is; positive effects (Anderson, Bordo and Duca, 2016; Grossl \& Tarassow, 2015; Kones, 2014; Carstensen, Hagen, Hossfield \& Neaves, 2008) negative effects (Nazar, Farshid \& Davood, 2011; Tillman, 2017; Higgins \& Manjin, 2009) both positive and negative effects (Anderson \& Duca, 2014) and no effects at all (Leippold \& Matthys, 2015; Bruggerman, Donati \& Warner, 2003; Kayongo \& Guloba, 2018). 
There also exist methodological differences in the estimation methods used for money demand. For example, most of the Uganda-specific studies are theoretically based on the macro specifications of money demand and its only Kayongo and Guloba (2018) which is based on the general equilibrium framework models of money demand. Some studies use VAR methodologies (Nabiddo, 2007; Kararach, 2002; Nachega, 2001) while (Guloba \& Osoro, 2009) use Dynamic Ordinary Least Squares (DOLS). Others like Kayongo (2017) and Kayongo and Guloba (2018) use the Autoregressive Distributed Lag $(A R D L)$ methodologies. Each of the methodologies has specific advantages over and above the other. It is important to note that the money demand results depend on the variables, estimation methods and period of estimation as also agreed by Sririam (2001). Stability tests largely conclude that Uganda's money demand is stable. The methodology is as discussed in Section three below.

\section{Methodology}

Sriram (2001) contends that a general function of all money demand models has both a scale variable and opportunity cost variables. This is as shown in equation 1 , with $(S V)$ signifying a scale variable and $(O C V)$ signifying opportunity cost variables. The scale variable is a representation of the level of economic activity in the country while the opportunity cost variables represent the opportunity cost of demanding for money. The opportunity cost of holding money involves both the own rate of return of money and the rate of return on alternative assets. Inclusion of both rates of return prevents the collapse of the model and helps to show the degree of substitutability between money and the other financial assets as a result of financial liberalization (Ericsson and Sharma; 1999). $M$ is the nominal monetary aggregate and $P$ is general price level. Economic theory also stipulates that demand for real money balances is homogeneous of degree zero in prices; this is an implication that money demand functions are modelled in real terms other than nominal ones. Currency substitution theories also incorporate other interest rates to account for the foreign effects on money demand (Mundell, 1963). Whereas exchange rate proxies for direct currency substitution, foreign interest rate proxies for indirect currency substitution or capital mobility (Leventakis, 1993).

$$
\frac{M}{P}=f(S V, O C V)
$$

The long run estimation for Uganda's money demand $(M / P)$ follows the reviewed literature and money demand modelling. The variables of choice include real GDP as a scale variable, and real exchange rate, interest rate spread, and inflation as the opportunity cost variables. It also includes an economic uncertainty index $(E U I)$. The economic uncertainty index is calculated using Generalized autoregressive conditional heteroscedasticity (GARCH) methodologies. It is extracted from the volatilities of critical money demand determinants like; national income, exchange rate, inflation, interest rate spread, foreign interest rate and a financial innovation proxy (currency outside banks). A positive effect on money demand is expected from national income and inflation while a negative effect is expected from interest rate spread, exchange rate and economic uncertainty.

The first level estimation is made of the linear $A R D L$ methodology, whose empirical long run specification is as expressed in equation 2. It is, however, important to note that before the $A R D L$ estimation is undertaken, properties of the timeseries of interest are explored by using unit root tests and correlation analysis. ARDL is only estimated if none of the variables is integrated of order 2 i.e. $I(2)$.

$$
\left(\frac{M}{P}\right)=f(R Y, I N F, R E X R, I R S, E V)
$$

The variables expressed in the model are in such a way that: $\frac{M}{P}$ represents the real money balances; $R Y$ represents real income; INF represents inflation; REXR represents real exchange rate; IRS represents the interest rate spread between the 91-day Treasury bill rate, and the time and saving deposit rate while $E V$ represents the economic uncertainty index.

Money demand estimation is estimated in a log linear form as shown in equation 3. However, some variables like interest rate spread, inflation and the economic uncertainty index are not log linearized because they are either rates or indexes. (However, those which are said not to be log-linearized are also log-linearized; this should be revised accordingly). 


$$
\ln \left(\frac{M}{P}\right)_{t}=\alpha_{1}+\alpha_{2} \ln R Y_{t}+\alpha_{3} I N F_{t}+\alpha_{4} \ln R E X R_{t}+\alpha_{5} I R S_{t}+\alpha_{6} E V_{t}+\varepsilon_{t}
$$

Where $\ln$ is the natural logarithm transformation; and $\varepsilon_{t}$ is the error term which assumes that $\varepsilon_{t} \sim n . i . i . d\left(0, \delta^{2}\right) . \alpha_{2}$, is expected to be positive because of the transaction motive of holding money; $\alpha_{3}$ is expected to be positive because economic agents are expected to demand for more money in the presence of inflation; $\alpha_{5}$ is expected to be negative; $\alpha_{4}, \alpha_{6}$, can either be positive or negative.

The paper uses the Autoregressive Distributed Lag (ARDL) method. The ARDL model is a dynamic single-equation regression equation used to predict values of the dependent variable based on both the current values of the explanatory variable and the lagged values of the explanatory variable. The paper uses the Autoregressive Distributed Lag method $(A R D L)$ because it hasn't been widely used for money demand estimations in Uganda. More particularly, the $A R D L$ method distinguishes between a dependent and explanatory variable; is able to simultaneously estimate both short run and long run coefficients; is relieved of the integration order; is more relevantly applied on a small sample; and can be applied on variables of differing optimal number of lag length. All variables in the ARDL estimation are assumed to be endogenous and the estimation is as stipulated in equation 4.

$$
\begin{aligned}
\Delta \ln \left(\frac{M}{P}\right)_{t} & =\alpha_{1}+\sum_{j=1}^{P} \gamma_{j} \Delta \ln \left(\frac{M}{P}\right)_{t-j}+\sum_{j=0}^{P} \delta_{j} \Delta \ln R Y_{t-j}+\sum_{j=0}^{P} \theta_{j} \Delta I N F_{t-j} \\
& +\sum_{j=0}^{P} \vartheta_{j} \Delta \ln R E X R_{t-j}+\sum_{j=0}^{P} \mu_{j} \Delta I R S_{t-j}+\sum_{j=0}^{P} \tau_{j} \Delta E V_{t-j}+\beta_{1} \ln \left(\frac{M}{P}\right)_{t-j} \\
& +\beta_{2} \ln R Y_{t-j}+\beta_{3} I N F_{t-j}+\beta_{4} \ln R E X R_{t-j}+\beta_{5} I R S_{t-j}+\beta_{6} E V_{t-j}+\varepsilon_{t}
\end{aligned}
$$

The differenced terms capture the short run effects while the variables in their levels capture the long run effects. Presence of a long run relationship is tested using the F-test since it determines the joint significance of lagged levels of the variables involved. The two sets of asymptotic critical values for the F-test developed by Pesaran et al. (2001) are: the lower critical bound and the upper critical bound. The lower critical bound assumes that all the variables are integrated of order zero I (0) and so there is no cointegrating relationship between the examined variables. However, the upper bound assumes that all the variables are integrated of order one I (1) meaning that there is no cointegration among the variables. In the presence of a long run cointegrating relationship, it warrants the estimation of an error correction model to estimate the short run coefficients. The error correction version of the $A R D L$ model is as shown in equation 5.

$$
\begin{aligned}
\Delta \ln \left(\frac{M}{P}\right)_{t}= & \alpha_{1}+\sum_{j=1}^{P} \gamma_{j} \Delta \ln \left(\frac{M}{P}\right)_{t-j}+\sum_{j=0}^{P} \delta_{j} \Delta \ln R Y_{t-j}+\sum_{j=0}^{P} \theta_{j} \Delta I N F_{t-j} \\
& +\sum_{j=0}^{P} \vartheta_{j} \Delta \ln R E X R_{t-j}+\sum_{j=0}^{P} \mu_{j} \Delta I R S_{t-j}+\sum_{j=0}^{P} \tau_{j} \Delta E V_{t-j} \\
& +\omega_{j} E C T_{t-1}+\varepsilon_{t}
\end{aligned}
$$

The ECT term represents the error correction term; this is derived from residuals from the estimated long run model in 4.

The crux of the linear $A R D L$ estimations is the assumption that all the variables have symmetric effects on monetary aggregates. However, this may not necessarily be the case; specifically, exchange rate may appreciation raise money demand while exchange rate depreciation may lower money demand; and the reverse is true. Therefore, to test this 
asymmetric hypothesis, changes in the real exchange rate variable $(\ln R E X R)$ are constructed to come up with $(\triangle \ln R E X R)$. In the newly constructed timeseries, positive exchange rate is denoted as $\triangle \ln R E X R^{+v e}$ and negative exchange rate is denoted as $\triangle \ln R E X R^{-v e}$. Using this notation, new time series are constructed, one reflecting positive shocks (POSEXR) and another reflecting negative shocks (NEGEXR). These are defined as partial sum of negative and positive changes. For the case of this paper, positive shocks (POSEXR) indicate a depreciation of the Uganda Shillings against the US Dollar while negative shocks (NEGEXR) indicate an appreciation of the Uganda Shillings against the US Dollar. These are as illustrated in equations 6 and 7.

$$
\begin{aligned}
& \operatorname{POSEXR}_{t}=\sum_{j=1}^{t} \Delta \operatorname{lnREXR_{j}^{+ve}}=\sum_{j=1}^{t} \max \left(\Delta \ln R E X R_{j}, 0\right) \\
& \operatorname{NEGEXR}_{t}=\sum_{j=1}^{t} \Delta \ln R E X R_{j}^{-v e}=\sum_{j=1}^{t} \min \left(\Delta \ln R E X R_{J}, 0\right)
\end{aligned}
$$

When $(\operatorname{lnREXR})$ in equations 4 and 5 is replaced by (POSEXR) and (NEGEXR), the non-linear ARDL estimation following Shin, Yu \& Greenwood-Nimmo (2014) is created. The long run non-linear ARDL estimation is as shown in equation 8 below.

$$
\begin{aligned}
\Delta \ln \left(\frac{M}{P}\right)_{t} & =\alpha_{1}+\sum_{j=1}^{P} \gamma_{j} \Delta \ln \left(\frac{M}{P}\right)_{t-j}+\sum_{j=0}^{P} \delta_{j} \Delta \ln R Y_{t-j}+\sum_{j=0}^{P} \theta_{j} \Delta I N F_{t-j} \\
& +\sum_{j=0}^{P} k_{j} \Delta \ln P O S E X R_{t-j}+\sum_{j=0}^{P} q_{j} \Delta \ln N E G E X R_{t-j}+\sum_{j=0}^{P} \mu_{j} \Delta I R S_{t-j} \\
& +\sum_{j=0}^{P} \tau_{j} \Delta E V_{t-j}+\beta_{1} \ln \left(\frac{M}{P}\right)_{t-j}+\beta_{2} \ln R Y_{t-j}+\beta_{3} I N F_{t-j} \\
& +\beta_{4} \ln \operatorname{POSEXR}_{t-j}+\beta_{5} \ln N E G E X R_{t-j}+\beta_{6} I R S_{t-j}+\beta_{7} E V_{t-j}+\varepsilon_{t}
\end{aligned}
$$

The short run non-linear $A R D L$ estimation is also as shown in equation 9.

$$
\begin{aligned}
\Delta \ln \left(\frac{M}{P}\right)_{t} & =\alpha_{1}+\sum_{j=1}^{P} \gamma_{j} \Delta \ln \left(\frac{M}{P}\right)_{t-j}+\sum_{j=0}^{P} \delta_{j} \Delta \ln R Y_{t-j}+\sum_{j=0}^{P} \theta_{j} \Delta I N F_{t-j} \\
& +\sum_{j=0}^{P} k_{j} \Delta \ln P O S E X R_{t-j}+\sum_{j=1}^{P} q_{j} \Delta \ln N E G E X R_{t-j}+\sum_{j=0}^{P} \mu_{j} \Delta I R S_{t-j} \\
& +\sum_{j=0}^{P} \tau_{j} \Delta E V_{t-j}+\omega_{j} E C T_{t-1}+\varepsilon_{t}
\end{aligned}
$$

There exist three forms of asymmetry, i.e.; short run asymmetry, adjustment asymmetry and long run asymmetry. The wald test on the null hypothesis of symmetry helps in testing for these asymmetries upon rejection of this null hypothesis. Consequently, the paper ascertains the type of asymmetry that exists for Uganda.

The paper also carries out different diagnostic tests to verify for the validity of the estimation. It uses tests like Breusch-Pagan and $A R C H$-heteroscedastic test to test for heteroscedasticity; Breusch-Godfrey to test for serial 
correlation and Jacque Bera test to test for normality. The stability tests are carried out by CUSUM and CUSUMQ tests.

\section{Results and Discussion}

\subsection{Data}

Secondary quarterly timeseries data are used for estimation for the period 2008Q3 to 2018Q4. This data is obtained from Uganda Bureau of Statistics (UBOS) and Bank of Uganda (BOU). Specifically, GDP data is obtained from Uganda Bureau of Statistics (UBOS) while monetary balances, exchange rate, interest rates and inflation are obtained from Bank of Uganda. The economic uncertainty index is calculated using the GARCH methodology, as a weighted index of volatilities of income, exchange rate, inflation, interest rate, foreign interest rate, and financial innovation, following Kayongo and Guloba (2018). Some data series are log-linearised and these are preceded by the letter "L" in the estimation. The period between 2008Q3 and 2018Q4 provides 42 data points which are used for estimation of this study. The detailed descriptive statistics for this study are as shown in the Annex 1.

The correlation results among the variables are also shown in Annex 2. There exists a high positive relationship between income and money demand. Whereas the correlations are positive between money demand and exchange rate, interest rate spread, and economic uncertainty index; they are not as high as it is with money demand and income. This is expected because money demand theories contend that there is a relationship between money demand and economic activity. On the other hand, there is a negative relationship between inflation and money demand.

\subsection{Unit Root Testing}

The study uses the Dickey-Fuller Generalised Least Squares (DF-GLS) unit root test procedure by Elliot et al. (1996). The DF-GLS unit root is prized to have significantly greater power than the Dickey Fuller (1979) and Phillips Perroni (1988) unit root tests. Apart from inflation which is integrated of order zero, all the other study variables are integrated of order one. This is as shown in Annex 3.

\subsection{Lag-Length Selection Criteria}

It is possible to estimate the linear ARDL methodology even when variables have a different lag length. The study uses the Akaike Information Criteria (AIC) to select the optimal lag length for estimation. The optimal lag length following the linear ARDL specification (LnRM2 | LnRGDP, LREXP, IRS, INF, EUI) is $(1,0,4,4,3,0)$. On the other hand, the lag length for the non-linear ARDL following the ARDL specification (LnRM2 | LnGRDP, POSEXR, NEGEXR, IRS, INF, EUI) is $(4,4,3,4,4,4,4)$.

\subsection{F-Bounds Cointegration Testing}

The F-Bounds cointegraton was estimated to show the existence of a long-term relationship between real money demand and its determinants. Indeed, both the ARDL and non-linear ARDL models confirmed the existence of long run relationships. This is because the F-test for both of the models was above the respective upper bounds at all levels of significance. This is as shown in Annex 4.

\subsection{Estimation Results}

Results from the linear ARDL reveal that that income, exchange rate, interest rate spread and economic uncertainty are positively related to real money demand in Uganda. However, inflation is negatively related to real money demand in Uganda, signifying that as inflation increases, economic agents decrease their demand for money. This is expected because inflation decreases the real value of money balances. This is as shown in Annex 5.

On the other hand, the short run results for the linear ARDL reveal that the error correction is negative and statistically significant. The ECT term is -0.316 with an interpretation that about 32 percent of the disequilibrium in money demand in the long run is corrected for in the next quarter. Contrary to the long run results, exchange rate and its lags have a negative relationship to money demand. This implies that whenever Uganda's exchange rate depreciates, economic agents and actors reduce their demand for money. This confirms expectation effects on money demand; that is, a weak domestic currency yields expectation for further weakening. Economic agents end up shifting their portfolios to other foreign currencies. Inflation maintains its negative relationship to Uganda's money demand even in the short run. Interest rate spread also maintains its positive relationship with money demand, signifying that as the interest rate spread increases.

In contrast to the linear ARDL long run results, the non-linear ARDL reveals that it is only income that is positively related to real money balances, while all the other variables are negatively related with real money balances. Of specific interest, an exchange rate depreciation of the Uganda Shillings against the US Dollar has negative effects on money demand just like an exchange rate appreciation. However, it is important to note that the exchange rate appreciation effects are not significant. Most importantly, an exchange rate depreciation of the Uganda shillings against the US 
Dollar has negative effects on money demand for the ARDL model but positive effects on money demand in for the non-ARDL model. This signifies the presence of exchange rate asymmetries of exchange rate on Uganda's money demand, as shown in Annex 6. This is also confirmed by the wald test results.

The error correction term for the non-linear ARDL model is twice as much as the linear ARDL model, indicating that any short-term distortions in Uganda's money demand are corrected for in the next quarter at a speed of adjustment of 0.6 in the long run.

An exchange rate depreciation of the Uganda Shillings against the US Dollar maintains a negative effect on Uganda's money demand in the short run non-linear ARDL model. However, an exchange rate appreciation of the Uganda Shillings against the US Dollar has a positive effect on money demand, that is people and economic agents demand more money when the exchange rate appreciates. This also confirms the asymmetric notion of exchange rate on Uganda's money demand.

On the other hand, interest rate spread, inflation and the economic uncertainty index are positively related to money demand in the short run. Of specific interest is the short run inflation result of the non-linear ARDL model which is contrary to the linear ARDL model.

\subsection{Diagnostic Tests}

The diagnostic tests show that both the symmetric ARDL and non-linear ARDL models are well specified. The Breusch Godfrey serial correlation and the Arch-heteroscedasticity tests fail to find serial correlation and heteroscedasticity for two models respectively at the one percent level of significance. The details of these are as shown in Annex 7.

\subsection{Stability Tests}

The CUSUM and CUSUMQ stability tests confirm stability of both the linear and non-linear ARDL models. This is as confirmed in the Annex 8.

\section{Conclusion and Policy Recommendations}

The paper has tested the symmetric and asymmetric effects of exchange rate on Uganda's real money demand for the period of 2008Q3 to 2018Q4. The paper uses both the linear ARDL and non-linear methodologies to estimate the symmetric effects and asymmetric effects respectively. This is the first study of its kind to explore this phenomenon in Uganda. This is also done with the inclusion of an economic uncertainty indicator to proxy uncertainty effects, especially in the advent of the novel coronavirus pandemic that has disrupted movement, trade, global value chains. The study findings will help in the effective execution of monetary policy and macro-management.

The error correction terms for both the linear and non-linear models are negative and significant, with that of the non-linear model twice as much as that one of the linear models. The study findings also confirm the existence of asymmetric effects of exchange rate on Uganda's money demand. In the linear ARDL model, depreciation of the Uganda Shillings against the US Dollar has a positive effect in the long run but a negative result in the short run.

On the other hand, the non-linear ARDL model reveals that a depreciation of the Uganda Shillings against the US Dollar negatively affects real money demand in the short run. In contrast, appreciation of the Uganda Shillings against the US Dollar positively affects real money balances. This confirms the asymmetric notion of exchange rate on Uganda's real money demand and also confirms the currency substitution hypothesis. The study diagnostics reveal that the model specifications are good and that Uganda's real money demand is stable.

The implication of these findings is that macro-economic policy management in Uganda should be cognizant of these asymmetric effects of exchange rate, for effective planning, policy and implementation. This is especially because an appreciation of the Uganda Shillings against the US Dollar has different results from a depreciation of the Uganda Shillings against the US Dollar. If such a phenomenon is misunderstood, it may lead to a false and poor economic planning and policy prescription.

\section{References}

Anderson, R. G., Bordo M., \& Duca, J. (2016). Money and velocity during financial crises: from the Great Depression to the Great Recession. Economics Working Paper 16111, Hoover Institution, Stanford University. https://doi.org/10.3386/w22100

Anderson, R. G., \& Duca, J. (2014). Money Demand and the Liquidity Accelerator in an Era of Financial Uncertainty and Innovation. Federal Reserve Banks of Dallas and St. Louis.

Arango S., \& Nadiri M. H. (1981). Demand for money in open economies. Journal of Monetary Economics, 7(1), 69-83. https://doi.org/10.1016/0304-3932(81)90052-0

Atingi-Ego, M., \& Matthews, K. (1996). Demand for narrow and broad money in Uganda. African Review of Money 
Finance and Banking, 69-85.

Attah-Mensah, J. (2004). Money demand and economic uncertainty. Bank of Canada working Paper 25.

Bahmani-Oskooee, M., \& Gelan, A. (2019). Asymmetric effects of exchange rate changes on the demand for money in Africa. Applied Economics, Taylor \& Francis Journals, 51(31), 3365-3375. https://doi.org/10.1080/00036846.2019.1578854

Bahmani-Oskooee, M., Miteza, I., \& Tanku, A. (2020). Exchange rate changes and money demand in Albania: a nonlinear ARDL analysis. Econ Change Restruct (2020). https://doi.org/10.1007/s10644-019-09261-9

Bahmani-Oskooee, M., \& Bahmani, S. (2015). Nonlinear ARDL Approach and the Demand for Money in Iran. Economics Bulletin, 35(1), 381-391

Bahmani-Oskooee, M., Kutan, A. M., \& Xi, D. (2013). The impact of economic and monetary uncertainty on the demand for money in Emerging Economies. Applied Economics. https://doi: 10.1080/00036846.2012.705430

Basu, S., \& Bundick, B. (2015). Uncertainty shocks in a model of effective demand. Boston College and National Bureau of Economic Research. https://doi.org/10.2139/ssrn.2531066

Baumol, W. J. (1952). The Transaction demand for Cash; An Inventory Theoretical Approach. The quarterly journal of economics, 66(4), 545-556. https://doi.org/10.2307/1882104

Bloom, N. (2009). The impact of uncertainty shocks. Econometrica, 77(3), 623-685. https://doi.org/10.3982/ECTA6248

Bloom, N., Kose, M. A., \& Terrone, M. E. (2013). Held back by uncertainty. Finance and Development, 38-41.

Bossone, B. (2014). Secular Stagnation. Economics Discussion Paper.

Bruggeman, A., Donati, P., \& Warner, A. (2003). Is the demand for Euro Area M3 Stable? ECB Working Paper, 255.

Carstensen, K., Hagen, J., \& Hossfield, O., \& Neaves, A. S. (2008). Money demand stability and inflation prediction in the four largest EMU countries. Kiel Working Paper. https://doi.org/10.1111/j.1467-9485.2009.00473.x

Choi, W. G., \& Oh, S. (2003). A money demand function with output uncertainty, monetary uncertainty and financial innovations. Journal of Money, Credit and Banking , 35(5), 685-709. https://doi.org/10.1353/mcb.2003.0034

Eggertsson, G. B., \& Mehrotra N. R. (2014). A model of secular stagnation. NBER Working Paper No. 20574. https://doi.org/10.3386/w20574

El-Rasheed Shehu, Hussin Abdullah \& Jauhari Dahalan. (2017). Monetary uncertainty and demand for money stability in Nigeria: An Autoregressive Distributed Lag Approach. International Journal of Economics and Financial issues, 7(1), 601-607.

Fischer, I. (1911). The purchasing power of money, its determinants and relation to credit, interest and crises. Macmillan, reprinted Newyork, Augustus M. Kelley 1963.

Friedman, M. (1956). The Quantity Theory of Money- a Restatement in the studies of Quantity Theory of Money. University of Chicago Press.

Friedman, M., \& Schwartz A. J. (1982). Monetary trends in the United States and the United Kingdom: Their relation to income, Prices, and Interest Rates.1867-1975. University of Chicago Press. https://doi.org/10.7208/chicago/9780226264257.001.0001

Greiber, C., \& Lemke, W. (2005). Money demand and Macroeconomic Uncertainty. Discussion paper series 1, Economic Studies.

Grossl, I., \& Tarassow, A. (2015). A microfounded model of money demand under uncertainty, and its empirical validation using co integration and rolling windows dynamic multiplier analysis. Universtat Hamburg.

Guloba, A., \& Osoro, N. (2009). Determinants and stability of money demand in Uganda during the period of economic liberalization. African Finance Journal: Special Issue 1, 142-161.

Higgins, M. L., \& Manjin S. (2009). Inflation uncertainty and money demand. Applied Economics letter. https://doi.org/10.1080/13504850701452023

Kararach, G. (2002). Evidence on the demand for money function in Uganda. https://doi.org/10.2139/ssrn.379880

Katarikawe, M., \&. Sebudde, R. (1999). Is the Reserve Money Program still a useful operating policy in Uganda for the conduct of Monetary Policy in Uganda? . Bank of Uganda Staff Paper, 1(1), 1-33.

Kateregga-Zalwango, E. (1993). The Determinants of the Demand for Money in Uganda: an econometric analysis.

Kayongo, A. (2017). Determinants and Stability of Uganda's money demand during Financial liberalization. Kampala: 
Unpublished Master's of Arts in Economics' Dissertation Makerere University.

Kayongo, A., \& Guloba, A. (2018). Economic Uncertainty and Money Demand Stability in Uganda during Financial Liberalization: A GARCH and ARDL Approach. Applied Economics and Finance, 5(4). https://doi.org/10.11114/aef.v5i4.3271

Keynes, J. M. (1935). The General Theory of Employment, Interest and Money. New York.

Kiptui, M. C. (2014). Some empirical evidence on the Stability of Money Demand in Kenya. International Journal of Economics and Financial Issues, 4(4), 849-858.

Kones, A. (2014). Impact of monetary uncertainty and economic uncertainty on money demand in Africa. Theses and Dissertations; Paper 629.

Leippold, M., \& Matthys, F. (2015). Economic policy uncertainty and the Yield Curve. https://doi.org/10.2139/ssrn.2669500

Leventakis, J. A. (1993). Modelling money demand in open economies over the modern floating rate period. Applied Economics, 25(8), 1005-1012. https://doi.org/10.1080/00036849300000080

Mahmood, H., \& Alkhateeb, T. T. Y. (2018). Asymmetrical effects of real exchange rate on the money demand in Saudi Arabia: A non-linear ARDL approach. PLoS ONE, 13(11). https://doi.org/10.1371/journal.pone.0207598

Mundell, R. A. (1963). Capital mobility and stabilization policy under fixed and flexible exchange rates. Canadian Journal of Economies and Political Science /Revue Canadienne de Economiques et Scinece Politique, 29(4), 475-485. https://doi.org/10.2307/139336

Nabiddo, W. (2007). The analysis of money demand for Uganda (1986:1-2003:4). Economic Policy Reserach Centre.

Nachega, M. J. C. (2001) Financial liberalization, money demand, and inflation in Uganda. International Monetary Fund. https://doi.org/10.5089/9781451854084.001

Nazar, D., Farshid, M., \& Davood M. (2011). Economic uncertainty- money demand nexus in Iran: Application of the EGARCH model and the ARDL approach. European Journal of Economic Finance and Administrative Sciences.

Nyorekwa, E. (2007). The demand for money in Uganda under reform period 1986-2005. Dar es Salaam: Unpublished Masters' dissertation from the University of Dar es Salaam.

Opolot, J. (2007) A re-examination of the demand for money in Uganda: Nature and Implications for monetary policy. The Bank of Uganda Staff Papers Journal, 1(1), 5-32.

Pesaran, M. H., Shin, Y., \& Smith, R. J. (2001). Bounds testing approaches to the analysis of level relationships. . Journal of applied econometrics, 16(3), 289-326. https://doi.org/10.1002/jae.616

Pigou, A. C. (1917). The Value of Money. Quarterly Journal of Economics, 32(38-65). https://doi.org/10.2307/1885078

Shin, Y., Yu, B. C., \& Greenwood-Nimmo, M. (2014). Modelling asymmetric cointegration and dynamic multipliers in a nonlinear ARDL framework. In R. Sickels \& W. Horrace (Eds.), Festschrift in honor of Peter Schmidt: Econometric methods and applications (pp. 281-314). New York, NY: Springer. https://doi.org/10.1007/978-1-4899-8008-3_9

Sriram, S. (2001). A survey of recent empirical money demand studies. IMF Staff Papers, 47(3).

Sriram, S. S. (2000). A Survey of Recent Empirical Money Demand Studies. Palgrave Macmillan Journals, 47(3).

Tillman, P. (2017). Monetary policy uncertainty and the response of the yield curve to policy shocks. School of Business and Economics-Phillips-University Marburg.

Tobin, J. (1956). The Interest Elasticity of Transactions demand for Cash. Review of Economics and Statistics, 38, 241-247. https://doi.org/10.2307/1925776 


\section{Appendix}

Annex 1. Descriptive Statistics

\begin{tabular}{lllllll}
\hline Variables & Observations & Mean & $\begin{array}{l}\text { Standard } \\
\text { Deviation }\end{array}$ & Median & Min. & Max \\
\hline LRM2 & 42 & 24.942 & 0.178 & 24.962 & 24.546 & 25.270 \\
LRGDP & 42 & 25.512 & 0.136 & 25.493 & 25.246 & 25.756 \\
LREXP & 42 & 3.011 & 0.089 & 3.048 & 2.830 & 3.138 \\
$I R S$ & 42 & -0.952 & 2.046 & -0.640 & -4.727 & 2.515 \\
$I N F$ & 42 & 2.139 & 2.289 & 1.857 & -2.061 & 8.290 \\
EUI & 42 & 0.588 & 0.334 & 0.702 & -0.439 & 1.014 \\
\hline
\end{tabular}

Annex 2. Correlation Matrix

\begin{tabular}{|c|c|c|c|c|c|c|}
\hline & LRM2 & $L R G D P$ & LREXP & $I R S$ & $I N F$ & $E U I$ \\
\hline LRM2 & 1 & & & & & \\
\hline$L R G D P$ & 0.931 & 1 & & & & \\
\hline LREXP & 0.310 & 0.152 & 1 & & & \\
\hline IRS & 0.601 & 0.597 & 0.340 & 1 & & \\
\hline$I N F$ & -0.278 & -0.232 & 0.135 & -0.024 & 1 & \\
\hline$E U I$ & 0.385 & 0.503 & -0.317 & -0.161 & -0.154 & 1 \\
\hline
\end{tabular}

Annex 3. Unit Root Tests

\begin{tabular}{|c|c|c|c|}
\hline \multirow[t]{2}{*}{ Variable } & \multicolumn{2}{|c|}{ DG-FLS } & \multirow[t]{2}{*}{ Order of Integration } \\
\hline & Level & First Difference & \\
\hline LRM2 & -1.969 & $-4.762 * * *$ & $\mathrm{I}(1)$ \\
\hline$L R G D P$ & -2.961 & $-8.496 * * *$ & $\mathrm{I}(1)$ \\
\hline LREXP & -2.523 & $-4.265 * * *$ & $\mathrm{I}(1)$ \\
\hline IRS & -3.319 & $-4.064 * * *$ & $\mathrm{I}(1)$ \\
\hline$I N F$ & $-3.709 * *$ & & $\mathrm{I}(0)$ \\
\hline EUI & -1.917 & $-9.098 * * *$ & I (1) \\
\hline
\end{tabular}

** and *** signify $5 \%$ and $1 \%$ levels of significance for the Elliott-Rothenberg-Stock DF-GLS test statistic

Annex 4. F-Bounds Test

\begin{tabular}{lll}
\hline & ARDL Value & Non-linear ARDL Value \\
\cline { 2 - 3 } & $\mathrm{K}=5$ & $\mathrm{~K}=6$ \\
\hline F-Statistic & 9.461 & 45.914 \\
95\% Bound (Lower, Upper) & $(2.734,3.92)$ & $(2.618,3.863)$ \\
$99 \%$ Bound (Lower, Upper) & $(3.657,5.256)$ & $(3.505,5.121)$ \\
\hline
\end{tabular}

Note: The figures in parentheses indicate both the lower and upper bound for the respective levels of confidence

Annex 5. Linear ARDL Results

\begin{tabular}{ll}
\hline Variable & Coefficient (Standard error) \\
\hline Long Run Results & \\
\hline$C$ & $14.27(15.109)$ \\
$\ln R G D P$ & $0.276(0.631)$ \\
$\ln R E X P$ & $1.216^{* *}(0.466)$ \\
$I R S$ & $0.016(0.029)$ \\
$I N F$ & $-0.095(0.051)$ \\
$E U I$ & $0.366(0.224)$ \\
\hline Short Run Results & \\
\hline$E C T$ & $-0.316^{* * *(0.034)}$ \\
$D(L R E X P)$ & $-0.072(0.106)$ \\
$D(L R E X P(-1))$ & $-0.442 * * *(0.105)$ \\
$D(L R E X P(-2))$ & $-0.417 * * *(0.098)$ \\
$D(L R E X P(-3)$ & $-0.283^{* *}(0.085)$ \\
$D(I R S)$ & $0.0058^{*}(0.003)$ \\
$D(I R S(-1))$ & $0.008^{* *}(0.003)$ \\
$D(I R S(-2))$ & $0.0077^{* * *}(0.003)$ \\
$D(I R S(-3))$ & $0.0095^{* * *}(0.003)$ \\
$D(I N F)$ & $-0.0112^{* * *}(0.00198)$ \\
$D(I N F(-1))$ & $0.0117^{* * *}(0.002)$ \\
$D(I N F(-2))$ & $0.0048^{* * *}(0.034)$ \\
\hline
\end{tabular}


Annex 6. Non-Linear ARDL Model Results

\begin{tabular}{|c|c|}
\hline Variable & Coefficient (Standard error) \\
\hline \multicolumn{2}{|l|}{ Long Run Results } \\
\hline$C$ & -18.891 \\
\hline $\ln R G D P$ & $1.7228 * * *(0.434)$ \\
\hline POSEXR & $-1.808 * *(0.014)$ \\
\hline$N E G E X R$ & $-3.931(1.863)$ \\
\hline $\operatorname{IRS}$ & $-0.0196 *(0.008)$ \\
\hline INF & $-0.035 *(0.157)$ \\
\hline EUI & $-0.176(0.101)$ \\
\hline \multicolumn{2}{|l|}{ Short Run Results } \\
\hline$E C T$ & $-0.600 * * *(0.0188)$ \\
\hline$D(\operatorname{LRM} 2(-1))$ & $-0.382 * * *(0.054)$ \\
\hline$D(\operatorname{LRM} 2(-2))$ & $0.148 *(0.065)$ \\
\hline$D(\operatorname{LRM} 3(-3))$ & $0.485 * * *(0.046)$ \\
\hline$D(L R G D P)$ & $-0.294 * * *(0.045)$ \\
\hline$D(L R G D P(-1))$ & $-0.522 * * *(0.051)$ \\
\hline$D(\operatorname{LRGDP}(-2))$ & $0.041(0.042)$ \\
\hline$D(\operatorname{LRGDP}(-3))$ & $0.643 * * *(0.043)$ \\
\hline$D(P O S E X R)$ & $-0.920 * * *(0.044)$ \\
\hline$D(\operatorname{POSEXR}(-1))$ & $-0.549 * * *(0.038)$ \\
\hline$D(P O S E X R(-2))$ & $-0.418 * *(0.036)$ \\
\hline$D(N E G E X R)$ & $0.950 * * *(0.055)$ \\
\hline$D(N E G E X R(-1))$ & $2.665 * * *(0.091)$ \\
\hline$D(N E G E X R(-2))$ & $1.825 * * *(0.077)$ \\
\hline$D(N E G E X R(-3))$ & $0.375^{* * *}(0.0536)$ \\
\hline$D(I R S)$ & $0.004 * *(0.0009)$ \\
\hline$D(\operatorname{IRS}(-1))$ & $0.016 * * *(0.001)$ \\
\hline$D(\operatorname{IRS}(-2))$ & $0.026 * * *(0.0009)$ \\
\hline$D(\operatorname{IRS}(-3))$ & $0.021 * * *(0.0009)$ \\
\hline$D(I N F)$ & $0.0005(0.0004)$ \\
\hline$D(\operatorname{INF}(-1))$ & $0.0169 * * *(0.0008)$ \\
\hline$D(I N F(-2))$ & $0.004 * * *(0.0006)$ \\
\hline$D(\operatorname{INF}(-3))$ & $0.005 * * *(0.0005)$ \\
\hline$D(E U I)$ & $0.0019(0.0129)$ \\
\hline$D(E U I(-1))$ & $0.0477 * *(0.0108)$ \\
\hline$D(E U I(-2))$ & $0.155^{* * *}(0.009)$ \\
\hline$D(E U I(-3))$ & $0.0546 * * *(0.007)$ \\
\hline
\end{tabular}

Annex 7. Diagnostic Tests and Stability Tests

\begin{tabular}{lll}
\hline & Linear ARDL Model & Non-Linear ARDL Model \\
\hline Diagnostic Tests & & \\
\hline Adjusted R-squared & 0.725 & 0.92 \\
F-Statistic & $77.48^{* * *}$ & $731.07^{* * *}$ \\
S.E. of Regression & 0.0221 & 0.0036 \\
Squared Residual Sum & 0.0128 & 0.00001 \\
DW & 1.717 & 2.52 \\
Breusch-Godfrey Test & $0.374(0.099)$ & $2.309(0.000)$ \\
Arch-Heteroscedasticity & $0.352(0.812)$ & $5.949(0.2)$ \\
JB Normality Test & 0.284 & 0.798 \\
Wald Test & & $11.7489^{* * *}$ \\
\hline Stability Tests & & \\
\hline CUSUM & Stable & Stable \\
CUSUMQ & Stable & Stable \\
\hline Figures
\end{tabular}

Figures in parentheses represent levels of significance 
Annex 8. CUSUM and CUSUMQ Stability Graphs

CUSUM Test for the linear ARDL Model
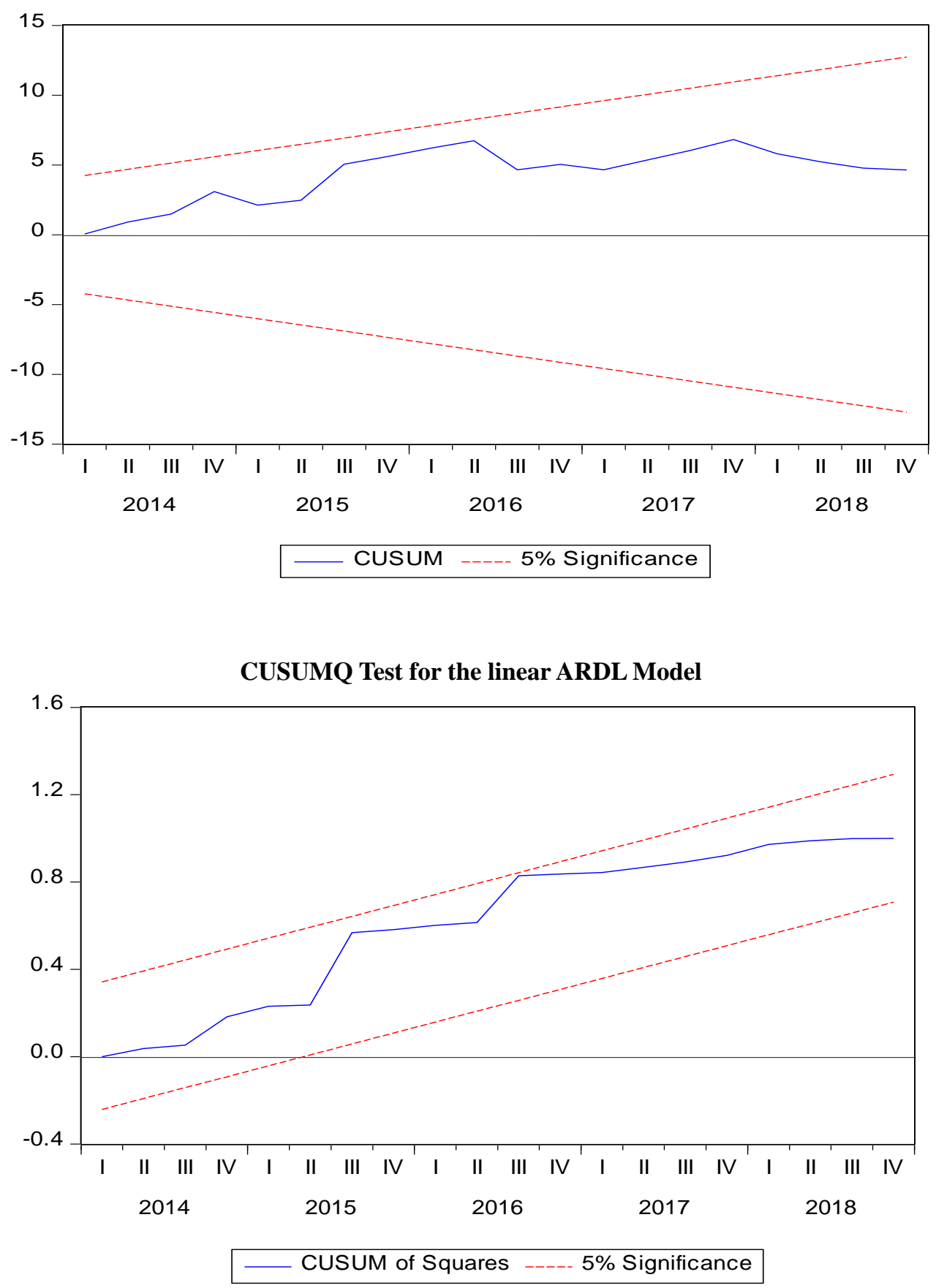


\section{CUSUM Test for the non-linear ARDL Model}

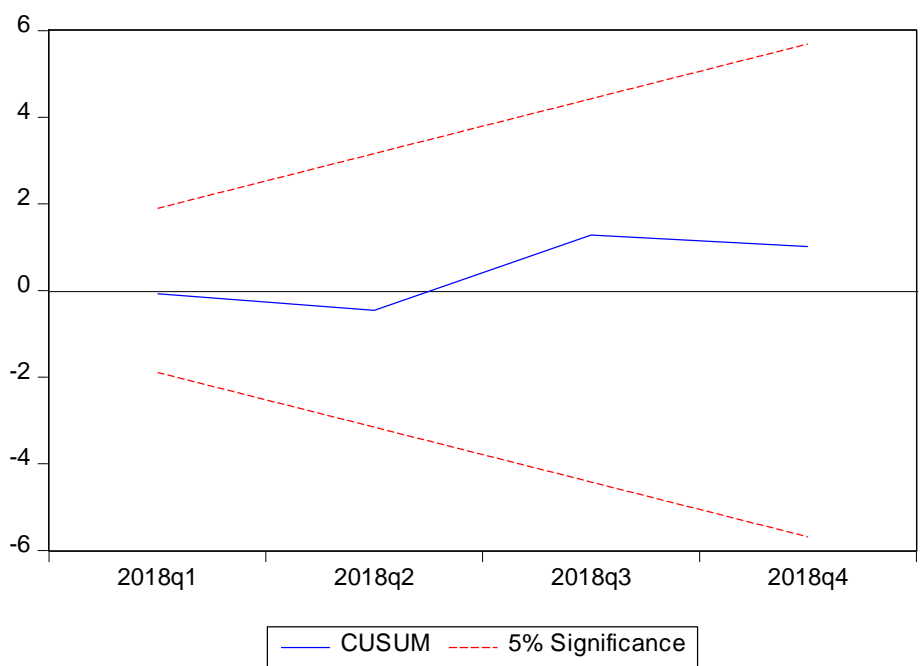

\section{CUSUMQ Test for the non-linear ARDL Model}

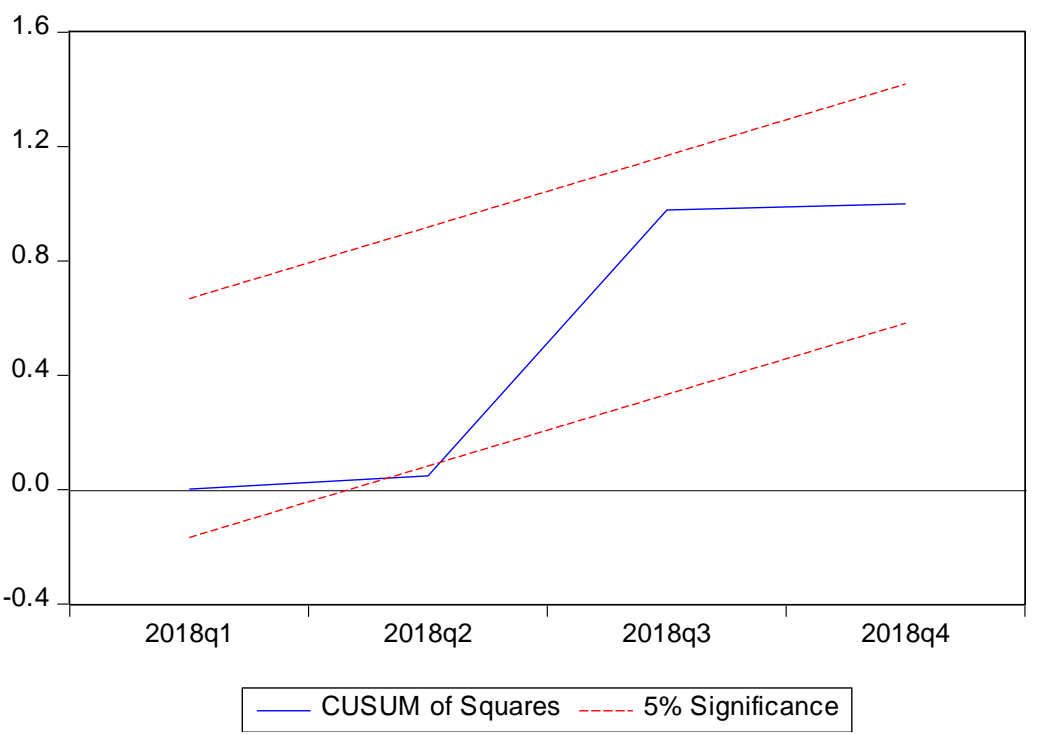

\section{Copyrights}

Copyright for this article is retained by the author(s), with first publication rights granted to the journal.

This is an open-access article distributed under the terms and conditions of the Creative Commons Attribution license which permits unrestricted use, distribution, and reproduction in any medium, provided the original work is properly cited. 